\title{
Człowiek w objęciach systemu. O Podróży do krainy zeków Julija Margolina
}

\author{
THE MAN IN THE GRIP OF THE SOVIET SYSTEM: \\ ON JULIUS MARGOLIN'S WORK JOURNEY TO THE LAND OF THE ZE-KA
}

\begin{abstract}
The article focuses on Julius Margolin's life and memoirs. Margolin was born in Pinsk, survived the Sovietization of Poland, and then spent five years in Soviet gulags. He witnessed the cruel history and functioning of the Soviet regime. The analysis is made on the basis of Margolin's work Journey to the Land of the Ze-Ka, in which he wanted to show to the world the truth about the Soviet totalitarian system. In that way he intended to fight for freedom of millions of people and for human rights.
\end{abstract}

Keywords: Julius Margolin, Journey to the Land of the Ze-Ka, Soviet camps, totalitarian system.

Słowa kluczowe: Julij Margolin, Podróż do krainy zeków, sowieckie łagry, totalitaryzm.

Julij Margolin - pisarz, filozof, zaangażowany syjonista, świadek sowietyzacji Polski, więzień sowieckiego obozu - wiele ma do opowiedzenia w kwestii historii Europy, tożsamości żydowskiej, ludzkiej godności, wolności i zagrożeń wyniszczających człowieczeństwo. Archiwum pisarza, dotychczas bardzo słabo opracowane zarówno w Polsce, jak i za granica, bez wątpienia zasługuje na pogłębioną eksplorację naukową. Podróż do krainy zeków, jego opus magnum, to obszerne objętościowo (ok. 700 stron) i doskonałe pod względem literackim dzieło wpisujące się w nurt literatury łagrowej. To jedno z pierwszych i ważniejszych świadectw sowieckiego 
totalitaryzmu, relacja z rosyjskiej Północy - symbolu zła, antywartości, zniewolenia, ludzkiej rozpaczy, śmierci. To wreszcie kolejne wybitne świadectwo pisarza z kręgu kultury żydowskiej¹.

Celem artykułu jest wprowadzenie nazwiska Margolina do polskich badań literaturoznawczych poprzez wstępne omówienie dokonań tego filozofa, pisarza, ale przede wszystkim świadka historii, dla którego najważniejszym zadaniem po wyjściu na wolność było przekazanie światu prawdy o Rosji sowieckiej.

Margolin długo pozostawał w cieniu innych świadków sowieckiego totalitaryzmu². Mimo że jego pierwsza relacja udostępniona została w 1948 r., czyli dwa lata przed Innym światem Gustawa Herlinga-Grudzińskiego (1951 r.) i kilkanaście lat przed Opowiadaniami kołymskimi Warłama Szałamowa czy Archipelagiem Gułag Aleksandra Sołżenicyna (lata siedemdziesiąte XX w.), nazwisko Margolina i jego Podróż do krainy zeków zaczęły zyskiwać na znaczeniu dopiero w XXI w.

Chociaż oryginalnym językiem wspomnień Margolina jest rosyjski, jego relacja z łagrów po raz pierwszy i jedynie częściowo - gdyż po ingerencji cenzury usunięto znaczną część tekstu ${ }^{3}$ - została opublikowana najpierw po francusku $(1949 \text { r. })^{4}$. W prace przekładowe i wydawnicze tamtej edycji Podróży zaangażowana była rosyjska pisarka, przedstawicielka tzw. pierwszej fali emigracji rosyjskiej, Nina Bierbierowa ${ }^{5}$. Kolejna edycja, tym razem rosyjskojęzyczna, ale również mocno okrojona przez cenzurę, która zmniejszyła objętość książki o dwanaście rozdziałów, ukazała się w Wydawnictwie Czechowa w Nowym Jorku w 1952 r. ${ }^{6}$ Pierwsza pełna publikacja zapisków Margolina ujrzała światło dzienne w 2011 r. we Francji. Wówczas książka ta została przetłumaczona na francuski przez profesor Sorbony, Lubę

${ }^{1}$ Tadeusz Sucharski, Literackie świadectwa polskich Żydów ze Związu Sowieckiego (z czasów II wojny światowej), [w:] Żydzi wschodniej Polski, Seria 2: W blasku i cieniu historii, red. Jarosław Ławski, Barbara Olech, Białystok 2014, s. 444.

${ }^{2}$ Roman Katsman, Putieszestwije w stranu zeka. Poeticzeskaja zagadka Julija Margolina, „Slavia Orientalis” 67 (2018), nr 4, s. 611.

${ }^{3}$ Zob. także: Tadeusz Sucharski, Literatura Holocaustu i literatura Gułagu? Literatura doświadczenia totalitarnego!, „Słupskie Prace Filologiczne. Filologia Polska” 5 (2007), s. 98.

${ }^{4}$ Misza Szauli, K priezientacyi dwuchtomnika Julija Margolina, http://www.newswe.com/ index.php?go =Pages\&in=view\&id=9186 [dostęp: 11 września 2018].

${ }^{5}$ Zob. Irina Winokurowa, Nie mogu siebie priedstawit', cztoby kniga nie wyszła po-russki... Kursiw moj: $k$ istorii publikacyi i riecepcyi, „Znamia” (2017), nr 12, http://magazines. russ.ru/znamia/2017/12/ne-mogu-sebe-predstavit-chtoby-kniga-ne-vyshla-po-russki-pr. html [dostęp: 26 stycznia 2019].

${ }_{6}$ Zob. Julij Borisowicz Margolin, Putieszestwije w stranu ze-ka. Priedisłowije, Nju Jork 1952, http://lib.ru/MEMUARY/MARGOLIN/Puteshestvie_v_stranu_ze-ka.txt [dostęp: 17 stycznia 2019]. 
Jurgenson, i wydana pod jej redakcją ${ }^{7}$. Po hebrajsku Podróż opublikowano w Izraelu w 2013 r., czyli ponad sześćdziesiąt lat po pierwszej edycji, i - co ciekawe - ponownie dzięki zaangażowaniu przedstawicieli rosyjskiej alii ${ }^{8}$. W tym samym roku wspomnienia doczekały się także polskiego wydania, a przekładu tekstu dokonał Jerzy Czech' ${ }^{9}$.

O tym, że nazwisko pisarza było w Izraelu przez długi czas na liście zakazanych, pisze Władimir Fromer, redaktor rosyjskojęzycznego czasopisma literackiego „Ami”. Wspomina, że dokumenty, które przedstawiał Margolin, były kłopotliwe, bo odsłaniały niewygodną prawdę historyczną ${ }^{10}$. Sam Margolin wielokrotnie pisał o bezdusznej znieczulicy i pasywnym zachowaniu Zachodu, także Izraela. Autor Podróży podziela stanowisko Sołżenicyna - zarzuca Zachodowi brak odwagi, zmowę polityczną, obojętność i „słabość wobec świata totalitarnego" ${ }^{11}$. Pisarz oskarża środowisko lewicowe w Izraelu - należy przypuszczać, że chodzi głównie o sympatyków rządzącej partii Mapai, którzy na jego relację odpowiadali milczeniem lub wrogością:

Przekonałem się, że w pewnych kręgach, a mianowicie w tych, których pomoc byłaby potrzebna najbardziej, nie wypada mówić głośno o niektórych zjawiskach w Związku Radzieckim. Ten, kto o tym mówi, wywołuje szok. Co więcej, naraża się na kompromitację [...]. Pisałem tę książkę przy milczącej i jawnej dezaprobacie swojego otoczenia i gdyby nie osobiste doświadczenie i siła przekonań, które zawdzięczam pięciu obozowym latom, możliwe, że uległbym zbiorowej sugestii, tak jak to robią inni uczestnicy „,zmowy milczenia” ${ }^{2}$.

7 Anna Maria Jackowska, Julius Margolin - świadek zagłady żydowskiej w obozach sowieckich. Przyczynek do dziejów zimnej wojny, „Dzieje Najnowsze” 43 (2011), nr 3, s. 99.

${ }^{8}$ Sympatię rosyjskojęzycznej emigracji zdobył Julij Margolin jako Żyd, syjonista, zawsze mocno związany z kulturą rosyjską. Roman Gul twierdzi, że pisarz kochał tę kulturę, kochał rosyjską inteligencję, rosyjską myśl, charakter, filozofię i muzykę. Margolin, według Gula, doskonale znał literaturę, żył jak typowy rosyjski inteligent, czerpiąc z rosyjskich tradycji i uparcie wierząc w dobro i sprawiedliwość. Zob. Władimir Chazan, Czełowiek, kotoryj byt „sam po siebie”. O Julii Margolinie, „Lechaim” 6 (ijun' 2010 / siwan 5770), https://lechaim.ru/ARHIV/218/hazan.htm [dostęp: 20 września 2018].

${ }^{9}$ Julius Margolin, Podróż do krainy zeków, tłum. Jerzy Czech, Wołowiec 2013, wersja pdf. Dalej cytuję według tego źródła. W zachodnim piśmiennictwie imię autora podawane jest najczęściej jako Julius.

${ }^{10}$ Władimir Fromier, Wmiesto poslestowija. Niesostojawszajasia wstriecza, [w:] Julij Margolin, Putieszestwije w stranu Zeka i doroga na Zapad, II, Jerozolima 2017, s. 312-313.

${ }_{11}$ Maria Bobrownicka, Lucjan Suchanek, Franciszek Ziejka, Wspótcześni Stowianie wobec własnych tradycji i mitów. Sympozjum w Castel Gandolfo 19-20 sierpnia 1996, Kraków 1997, s. 157.

12 Margolin, Podróż do krainy zeków..., s. 347. 
Misja Margolina za jego życia (zmarł w roku 1971) stała się niemożliwa do wypełnienia, świat bowiem długo nie chciał słuchać tej relacji z łagrów ${ }^{13}$. Nawet wystąpienie pisarza w roli świadka na sesji Rady Gospodarczej i Społecznej ONZ w 1950 r. nie przyniosło zamierzonych rezultatów. Jego świadectwo wywołało wówczas ostry sprzeciw sowieckiego delegata Siemiona Carapkina, a Margolin zamiast sojuszników zyskał kolejnych wrogów ${ }^{14}$.

Ukłonem w stronę zmarłego pisarza jest ponowne - najpełniejsze do tej pory - wydanie w 2017 r. pod redakcją Miszy Szaulego wspomnień Margolina; w edycji tej po raz pierwszy udostępnione zostały nowe zapiski autora zebrane w rozdziale Droga na Zachód. Swoistym epilogiem jest tam artykuł wspomnieniowy Władimira Fromera omawiający losy samego Margolina i okoliczności zakłócające publikację jego tekstów ${ }^{15}$. Jedną z prób rehabilitacji jest także esej Anatolija Jakobsona z wymownym podtytułem: Próba requiem. Autor przeprasza w nim nieżyjącego pisarza za to, że przez długie lata jego działania były blokowane, a jego krzyk z otchłani nie został wysłuchany ${ }^{16}$. W ostatnim czasie w Izraelu wznawiane są prace nad zbiorem Margolinowskich rękopisów i zebranych przez pisarza dokumentów przechowywanych w Centralnym Archiwum Syjonistycznym w Jerozolimie; pojawiają się także artykuły naukowe poświęcone życiu i twórczości pisarza.

Twórczość Margolina i jego zaangażowanie w walkę z sowietyzmem wysoko cenił Roman Gul, redaktor naczelny czasopisma rosyjskiej emigracji „Nowyj Żurnał”17, wydawanego od 1942 r. w Nowym Jorku. Pisarze przyjaźnili się, a Gul zabiegał o publikację fragmentów Podróży w jednym z paryskich wydawnictw ${ }^{18}$. Przychylną ocenę w latach pięćdziesiątych wystawił zapiskom Margolina również Wiktor Sukiennicki, historyk, sowietolog, wieloletni więzień sowieckich obozów, współpracownik paryskiego czasopisma „Kultura”19. O konieczności wszczęcia polskich badań nad

${ }^{13}$ Fromier, Wmiesto poslestowija..., s. 315.

${ }_{14}$ Julij Margolin. Kratkij oczerk żyzni i tworczestwa (Iz biograficzeskogo oczerka, napisannogo Gołdoj Jellin w 1997 godu), [w:] Julij Margolin, Putieszestwije w stranu Zeka i doroga na Zapad, I, Jerozolima 2017, s. 4.

${ }^{15}$ Fromier, Wmiesto poslestowija..., s. 313-323.

${ }^{16}$ Anatolij Jakobson, Fragmienty iz Margolina (Popytka riekwijema), http://www.antho. net/library/yacobson/texts/margolin.html [dostęp: 16 stycznia 2019].

${ }_{17}$ Szkice. Opowiadania. Sprawozdania, „Kultura”, Paryż (wrzesień 1986), s. 165.

${ }_{18}$ Roman Gul, Ja unios Rossiju. Apołogija emigracyi, t. 1: Rossija w Giermanii, Moskwa 2001, s. 16, 248.

${ }_{19}$ Zob. omówienie artykułu: Wiktor Sukiennicki, Z ziemi nieludzkiej - relacje obcych i swoich, „Kultura” (1950), nr 11 (37), http://www.kulturaparyska.com/pl/historia/wycinki/ 1951/6 [dostęp: 16 stycznia 2019]. 
twórczością Margolina pisała w 2011 r. Anna Maria Jackowska - archiwistka podejmująca w swoich pracach temat zagłady żydowskiej w obozach sowieckich $^{20}$.

\section{Julij Margolin. (Auto)biografia}

Najrzetelniejszym źródłem informacji o życiu i twórczości Margolina są opracowania Gołdy Jellin, pochodzącej z Chersonia na Ukrainie syjonistki zaangażowanej w sprawy rosyjskojęzycznej alii w Izraelu, liderki organizacji walczącej o prawo Żydów z ZSRR do repatriacji ${ }^{21}$. Dokonując w tym artykule przeglądu życia i dorobku Margolina, powołuję się głównie na opracowany przez nią rosyjskojęzyczny biogram pisarza, zamieszczony w najnowszym, pełnym wydaniu Podróży do krainy zeków: Putieszestwije w stranu Zeka i doroga na Zapad (Jerozolima 2017) ${ }^{22}$.

Julij (Jehuda) Borysowicz Margolin urodził się w 1900 r. w Pińsku na Polesiu, zmarł w 1971 r. w Tel Awiwie. Jego ojciec był lekarzem. Rodzina sporo podróżowała po świecie, lecz Julij wychowywał się głównie w Pińsku i Jekaterynosławiu (obecnie Dniepr na Ukrainie). Od 1926 r. wraz z żoną Ewą Spektor mieszkał w Łodzi. Wyższe wykształcenie zdobył na uniwersytecie w Berlinie, gdzie studiował filozofię. Studia ukończył w 1935 r. ze stopniem doktora. Rozprawę doktorską poświęcił zagadnieniu świadomości intencjonalnej (Grundphänomene des intentionalen Bewußtseins ${ }^{23}$ ). Rok później Margolin, pewny swoich poglądów syjonista, zwolennik ideologii Żabotyńskiego, autor książki Idea syjonizmu (1936), wyjechał z żoną i synem do Palestyny. Tam otrzymał prawo do stałego pobytu, ale w $1939 \mathrm{r}$. z powodów osobistych i zawodowych wrócił na jakiś czas do Polski, gdzie zastała go wojna. Mimo wielu zabiegów, a także legalnych i nielegalnych prób przekroczenia granicy, nie udało mu się wyjechać z terenów okupowanych. Szukając możliwości ucieczki, przebywał w Śniatyniu, Czortkowie i we Lwowie (gdzie nie uległ iluzji komunistycznego dobrobytu), aż w końcu

${ }^{20}$ Jackowska, Julius Margolin ..., s. 99.

${ }^{21}$ Irina Dobruskina, Iz awtobiograficzeskich matieriałow i publicystiki, „Lethaea Rossica" 9 (2014), s. 87. Po śmierci Jellin w 2000 r. pieczę nad archiwum Margolina przejęła Irina Dobruskina.

${ }_{22}$ Julij Margolin. Kratkij oczerk żyzni..., s. 3-5. Zob. także: Szauli, K priezientacyi dwuchtomnika Julija Margolina...

${ }_{23}$ Julij Margolin, Niesobrannoje, Tel Awiw 1975, s. 439. Przywołuję za: Katsman, Putieszestwije w stranu zeka..., s. 612. W Berlinie Margolin współpracował ze środowiskiem emigracji rosyjskiej, uczęszczał na seminarium filozofa i krytyka literackiego Julija Eichenwalda. 
dotarł do rodzinnego Pińska ${ }^{24}$. W czerwcu 1940 r. został aresztowany, ale mimo wszystko nie zdecydował się przyjąć sowieckiego paszportu. Uznany za „element społecznie niebezpieczny”, został oskarżony o nielegalne przebywanie na terenach sowieckich i skazany na pięć lat pracy przymusowej. Pisarz w latach 1940-1945 „przeszedł przez trzy więzienia i osiem obozów pracy; najważniejsze spośród nich to 48 Kwadrat w łagpunkcie Ostricz (w Białomorsko-Bałtyckim ITŁ ${ }^{25}$ ), następnie Kruglica i Osinówka (w Kargopolskim ITŁ), a także obóz tranzytowy w Kotłasie"26. Po odbyciu kary Margolin wciąż nie mógł wrócić do Polski, nie dostał też zgody na wyjazd do Palestyny. Dopiero pod koniec roku 1946 pisarz dotarł do ojczyzny.

\section{Margolin i sprawa Bergera}

W trakcie podróży statkiem do Palestyny Margolin napisał List otwarty zatytułowany Sprawa Bergera. Dokument został opublikowany w 1947 r. w czasopiśmie emigracyjnym „Socyalisticzeskij wiestnik” i stanowi preludium do Podróży, ułatwia właściwe odczytanie wspomnień, systematyzuje wiedzę na temat losów pisarza oraz jego światopoglądu. Margolin relacjonuje w nim ${ }^{27}$ :

Od jesieni 1939 do lata 1946 roku, siedem bez mała lat, przeżyłem w Związku Radzieckim. Z tego pierwszy rok na terenie okupowanej Polski. Byłem tam świadkiem procesu sowietyzacji podbitego kraju. Widziałem, jak się przeprowadza „plebiscyt”, jak wyrabia się w ludziach „entuzjazm” i „radziecki patriotyzm”. Następnie pięć lat przebywałem na katordze, w tzw. obozach pracy przymusowej, i to właśnie w nich poznałem tajemnicę stabilności i siły tamtejszego ustroju. Ostatni rok, już na wolności i w zgodzie z prawem, spędziłem w małym mieście w Kraju Ałtajskim, żyjąc powszednim, szarym, pracowitym życiem człowieka radzieckiego ${ }^{28}$.

Wstęp Listu, emocjonalnie dojrzały i uporządkowany, jest osobistym zwierzeniem autora, który z inteligenta głoszącego przed rokiem 1939 neutralny stosunek do systemu sowieckiego zmienia się w ciągu kilku lat w radykalnego antykomunistę:

${ }^{24}$ Zob. Jackowska, Julius Margolin..., s. 101-102.

${ }^{25}$ ITŁ - Isprawitielno-Trudowoj Łagier, tj. Poprawczy Obóz Pracy.

${ }^{26}$ Tamże, s. 103.

${ }^{27}$ Czasopismo wydawane było w latach 1921-1965 przez środowiska mienszewików, najpierw w Berlinie, a następnie w Paryżu i Nowym Jorku.

${ }^{28}$ Cyt. za: Jerzy Czech, ...mówilibyśmy nie „archipelag GUŁag”, ale „kraina zeków”, [w:] Margolin, Podróż do krainy zeków..., s. 7 
Siedem minionych lat uczyniło ze mnie zdecydowanego, zawziętego wroga ustroju radzieckiego. Nienawidzę go całym sercem, całą mocą swoich myśli. Wszystko, co zobaczyłem, napełniło mnie przerażeniem i wstrętem na resztę życia. Zrozumie mnie każdy, kto tam był i widział to samo co ja. Uważam, że walka z niewolniczym, terrorystycznym i nieludzkim reżimem, który tam panuje, stanowi pierwszy obowiązek każdego uczciwego człowieka na całym świecie... [...]. Nie mam ambicji literackich. Moim celem jest prawda ${ }^{29}$.

Margolin od razu po wyjściu na wolność podejmuje wyścig z czasem, automatycznie wcielając się w rolę „posłańca prawdy”30. Czas teraźniejszy, który wyznaczał kierunek jego obozowej biografii odartej z przeszłości i pozbawionej nadziei na przyszłość, znów zyskuje na znaczeniu. Dla tych, którym udało się wydostać z łagru i dostali szansę zdania relacji z „wczoraj”, jak pisze Izabella Sariusz-Skąpska, omawiając twórczość Beaty Obertyńskiej, ważne jest to, co „dzisiaj” dzieje się tam, w obozie ${ }^{31}$. Przywracanie pamięci i utrwalanie jej na papierze jest dla Margolina jak katharsis. Autor przyjmuje perspektywę ostatniego dnia swojego życia, gdyż jutro, jak twierdzi, może być już za późno. Przekazywana Zachodowi relacja pozwala na realizację przyrzeczenia danego sobie i ,ludziom nigdy niezapomnianym"32. W drodze z Rosji sowieckiej do domu Margolin składa taką oto deklarację:

los włożył mi do ręki pióro. Nie odłożę go, dopóki nie opiszę wszystkiego, co mam do powiedzenia. Nie mam ambicji literackich. Moim zadaniem jest powiedzieć prawdę, której tak wielu ludzi nie ma odwagi, nie chce, nie wie jak, lub po prostu boi się powiedziećs3.

Przywoływana w Liście postać doktora Bergera ma znaczenie symboliczne. Jego historia jest symbolem losów milionów ludzi bezlitośnie „wymazanych z księgi życia”"34 - więźniów różnych narodowości, wyznań i poglądów. O ile jednak w Podróży to refleksje natury ogólnoludzkiej stanowią trzon rozważań Margolina, o tyle w Liście mocno podkreśla on swoje

29 Tamże, s. 8-9. Zob. także: Julij Margolin. Kratkij oczerk żyzni..., s. 9.

${ }_{30}$ Andrzej Drawicz, Chory kraj, chorzy ludzie, co dalej?, [w:] Emigracja i tamizdat. Szkice o współczesnej prozie rosyjskiej, red. Lucjan Suchanek, Kraków 1993, s. 105.

31 Izabella Sariusz-Skąpska, Polscy świadkowie GUŁagu. Literatura łagrowa 1939-1989, Kraków 1995, s. 141.

${ }^{32}$ Tamże.

33 Julij Margolin, Wiesti iz Rossii. Dieło Biergiera (Otkrytoje pis'mo), Czernowik, pieriepieczatannyj na maszynkie po-russki, „Socyalisticzeskij Wiestnik” (1946), nr 12, s. 275-278, http://rjews.net/raisa-epshtein/articles/margolin/6.htm [dostęp: 7 września 2018]; tłumaczenie autorki artykułu.

${ }^{34}$ Tamże. 
syjonistyczne poglądy i pochodzenie żydowskie. Ten ostatni dokument jest kartą pamięci o Żydach zniewolonych przez system sowiecki i uwięzionych za drucianym ogrodzeniem „radzieckiego podziemnego królestwa” - bez prawa do wolności i do samookreślenia się. Jest także patetyczną odezwą do narodu żydowskiego, by pamięć o nich ocalić od zapomnienia. Jako przedstawicieli zniewolonej społeczności żydowskiej Margolin przywołuje w Liście dwie postacie: Wieniamina Bergera i Mojszego Kulbaka.

Tytułowy bohater - Wieniamin Berger - przed wojną zajmował stanowisko przewodniczącego organizacji syjonistycznej na Litwie. Jako „element społecznie niebezpieczny” dla Związku Radzieckiego został skazany na dziesięć lat katorgi. Obaj z Margolinem odbywali wyrok w obozie kotłaskim. Doktor Berger - ikona myśli syjonistycznej - zyskał ogromy szacunek pisarza, gdy z poświęceniem ratował współwięźniów od śmierci ${ }^{35}$. To jemu właśnie Margolin zawdzięcza życie, dzięki niemu nie zginął śmiercią głodową.

Kolejna, wielka w oczach Margolina postać - Mojsze Kulbak - poeta, prozaik i publicysta tworzący w języku jidysz, został w roku 1937 aresztowany przez NKWD i osadzony w łagrze z zarzutem szpiegostwa. W tym samym czasie również jego książki znalazły się na liście zakazanych. Co ciekawe, urodzony na Wileńszczyźnie Kulbak nie był syjonistą, akceptował politykę Związku Sowieckiego, a nawet fascynował się komunizmem. Ostatecznie w tym samym $1937 \mathrm{r}$. po sfingowanym procesie został rozstrzelany ${ }^{36}$.

Margolin pisze o niepospolitych umiejętnościach Bergera i nieprzeciętnym talencie Kulbaka. Wyczuwa się emocjonalne zaangażowanie autora, gdy wspomina prześladowanego poetę. Wówczas łagodnieje pompatyczny, sołżenicynowski, „obciążony funkcją”, „ładunkiem dydaktycznym” ${ }^{37}$ styl Margolina, momentami stając się liryczny, rzewny, a określenia „nasz”, „nasze” potwierdzają żydowską tożsamość autora. W Liście otwartym dochodzą do głosu jego syjonistyczne przekonania o konieczności integracji i społecznego zaangażowania w tworzenie nowej izraelskiej państwowości. Jednak, jak twierdzi Margolin, bez realnych, etycznie odpowiedzialnych działań, również w tak ważnej kwestii jak sowieckie łagry, syjonistyczne

${ }^{35}$ Zob. S. N. Cziżyk, Sud'ba odnoj prokłamacyi: izrailskij kommunizm protiw Julija Margolina. Sobranije statiej i wystuplenij, obraszczenij i pisiem Julija Margolina 1946-1957 gg., Jerozolima 2002, s. 40.

${ }^{36}$ Zob. Avraham Novershtern, Kulbak Moyshe, [w:] The YIVO Encyclopedia of Jews in Eastern Europe, https://yivoencyclopedia.org/article.aspx/Kulbak_Moyshe [dostęp: 9 czerwca 2020].

37 Drawicz, Chory kraj, chorzy ludzie..., s. 111-112. 
środowisko to „moralny trup”38, ulegnie rozkładowi i zablokuje rozwój państwa Izrael.

Margolin pisze też o ciążącym na każdym obywatelu Zachodu obowiązku podjęcia walki z „Rosją szatana”. Wspominając o „zafałszowanych wyrokach”, „nieograniczonym cynizmie władzy sowieckiej”, o „maszynie śmierci”, która w odróżnieniu od okrutnych hitlerowskich obozów nadal zabija $^{39}$, apeluje do świata o interwencję w obronie prawdziwego człowieczeństwa i gloryfikowanej w tekście Podróży tożsamości zachodnioeuropejskiej, z nią bowiem autor się utożsamia jako człowiek Zachodu, obrońca demokracji i uniwersalnych wartości.

Pisarz wracał do Palestyny w 1946 r. z nadzieją, że znajdzie tam ludzi, którzy będą mu współczuć, ale przede wszystkim zechcą pomóc, wysłuchają jego relacji i podejmą działania. Bardzo szybko jednak doznał rozczarowania, gdyż w wielu przypadkach zwyciężała poprawność polityczna - izraelski komunizm i służalczość jego przedstawicieli wobec rosyjskiej ideologii. Warto wspomnieć, że początkowo żydowski jiszuw był pod wzmożonym wpływem ZSRR, który poparł nawet powołanie państwa izraelskiego w 1948 r. na forum ONZ. Współpraca Erec Israel z ZSRR miała sprzyjać budowaniu potęgi „ojczyzny proletariatu”, ochraniać mit o doskonałościach systemu sowieckiego i komunistycznym dobrobycie ${ }^{40}$ :

Moim obowiązkiem i pierwszym ruchem po powrocie na Zachód było zdać sprawę z tego, co przeżyłem i przekazać wołanie o pomoc ludzi odciętych od świata. Ale dopiero tutaj, wśród wolnych ludzi Zachodu, zrozumiałem całą otchłań nieszczęścia tych, którzy pozostają w zamknięciu. Wyrwawszy się spoza drutów obozu, natknąłem się na kamienny mur małoduszności i zdrady ${ }^{41}$.

Człowiek słaby w bardziej uniwersalnym Margolinowskim ujęciu to ten, który nabiera wody w usta, milczy, gdy łamane są podstawowe prawa człowieka. Ludzie słabi, jak stanowczo głosi autor, utracili honor i są współodpowiedzialni za haniebne czyny, stając się „wspólnikami zbrodni”42. Pisarz nie ma wątpliwości, że „każda zbrodnia na świecie powinna być ujawniona

${ }^{38}$ Margolin, Wiesti iz Rossii...

39 Tamże. Według danych (z 2016 r.) Federalnego Urzędu Więziennictwa w łagrach rosyjskich, w katorżniczych warunkach, przebywa ponad 600 tysięcy osób; miejscami zsyłek są: Republika Mordowii, Syberia, Ural. Zob. Kazimierz Pierzchała, Rosyjski system penitencjarny w ujęciu wybranych polskich i rosyjskich opracowań, „Nowa Polityka Wschodnia” (2017), nr 4, s. 65-66.

${ }_{40}$ Zob. Cziżyk, Sud'ba odnoj prokłamacyi...

${ }^{41}$ Margolin, Podróż do krainy zeków..., s. 347.

42 Tamże. 
i nazwana po imieniu [...]. Żaden przypadek naruszenia praw człowieka nie może być anonimowy"43. Brak reakcji na okrucieństwo sowieckiego systemu, podobnie zreszta jak w przypadku działań antysemickich, według Margolina przeczy demokracji, świadczy o braku przyzwoitości. Metaforyczny obraz świata (autor wręcz nadużywa określeń: „zajęczy strach”, „nędzny strach”, „rezerwat niewolników” ${ }^{44}$ ) ma jedynie wzmocnić siłę głosu pisarza wzywającego ludzkość do śmiałej obrony człowieczeństwa, do odważnej walki w obronie życia i wolności. Istotną cechą pisarstwa Margolina jest afirmacja człowieka myślącego. Homo sapiens, w odróżnieniu od homo sovieticus, ma świadomość swoich praw, potrafi walczyć o wolność i sprawiedliwość. Zaimki każdy i żaden wykluczają możliwość jakiegokolwiek usprawiedliwienia haniebnych, zbrodniczych czynów.

\section{Podróż do krainy zeków}

Po wyjściu na wolność Margolin czuł się zobowiązany przekazać światu prawdę i uczynił to, jak sam twierdzi, z kilku powodów. Po pierwsze, chciał pokazać skalę sowieckiej dyktatury i „szarą codzienność, pospolitość łagrów" "45. Po drugie, odtworzył swoje wspomnienia po tym, jak w lipcu 1944 r. na terenie więzienia tranzytowego strażnik NKWD z zimną krwią zniszczył rękopisy jego trzech prac. Bezpowrotnie zaprzepaszczone zostały wtedy: Teoria kłamstwa, Teoria nienawiści oraz Teoria wolności. „Przepadł tragiczny i dziwny paradoks - książka o kłamstwie pisana pośród kłamstwa, księga o nienawiści pisana pośród nienawiści, książka o wolności pisana w więzieniu"46 - relacjonuje Margolin.

Podróż do krainy zeków reprezentuje niefikcjonalną prozę autobiograficzną ${ }^{47}$, która walczy z fałszem i weryfikuje półprawdę historyczną ${ }^{48}$. To dokument, w którym ważna jest motywacja: ma wstrząsnąć sumieniem ${ }^{49}$,

43 Tamże.

${ }^{44}$ Tamże, s. 347-348.

45 Tamże, s. 345.

46 Tamże, s. 315.

${ }^{47}$ Izabela Kowalska-Paszt, Proza niefikcjonalna trzeciej fali emigracji rosyjskiej. Model typologiczny, Szczecin 2001, s. 58.

${ }_{48}$ Zob. Lucjan Suchanek, O postawach pisarzy rosyjskich, [w:] Dać świadectwo prawdzie. Portrety wspótczesnych pisarzy rosyjskich, red. Lucjan Suchanek, Kraków 1996, s. 51.

49 Por. Tadeusz Sucharski, Polskie poszukiwania „innej” Rosji. O nurcie rosyjskim w literaturze Drugiej Emigracji, Gdańsk 2008, https://terytoria.com.pl/1046-e-book-polskie-poszukiwania-innej-rosji.html [dostęp: 10 września 2019]. 
„opowiedzieć Zachodowi"50 o państwie Stalina, ujawnić sowieckie zbrodnie, podważyć logikę systemu komunistycznego, a także uczcić pamięć o ofiarach. Książka, nad którą Margolin pracował około dziewięciu miesięcy, jest jego reakcją na wszechobecne w ZSRR kłamstwo, które będąc wypadkową fałszywej ideologii, niszczy istotę ludzką i pozbawia ją człowieczeństwa. Według jego personalistycznej koncepcji sprzeciw wobec kłamstwa i nienawiści jest „pierwszym przejawem ludzkiej wolności”"51.

Tekst Margolina to świadectwo nietypowe, dalekie od świadectw aliterackich, tekstów niewykończonych, pisanych kurczowo, jakby wstępnie, schematycznie naszkicowanych ${ }^{52}$. W odróżnieniu od wielu relacji łagrowych, często lakonicznych, minimalistycznych pod względem formy i stylu, jest to książka przemyślana, z pogranicza dokumentu osobistego i literatury pięknej ${ }^{53}$, gdzie rzeczywistość, jak pisze Roman Katsman, zanurzona jest w estetyczno-psychologiczne głębiny ${ }^{54}$. I rzeczywiście, płaszczyzna psychologiczno-antropologiczna w odmianie ufilozoficznionej jest w Podróży dominująca ${ }^{55}$. Na uwagę zasługuje też język - wirtuozersko dopracowany i, co ważne, nienaznaczony brutalnym piętnem obozu, który nie apoteozę przemocy ${ }^{56}$ głosi, lecz wiarę w człowieka. Nie znaczy to, że świadectwo Margolina zatraca swoje walory faktograficzne, funkcjonalne, o jakich pisze Eugeniusz Czaplejewicz, dokonując przeglądu kolejnych okresów w rozwoju literatury łagrowej ${ }^{57}$. Autor, pisząc Podróż, był doświadczonym literatem, miał już spory dorobek dziennikarski, wydawniczy, literacki ${ }^{58}$, z lekkością dokonuje więc niefikcjonalnej i artystycznie doskonałej syntezy.

${ }^{50}$ Powiedz Zachodowi to tytuł wydanej w 1946 roku w Nowym Jorku książki Jerzego Gliksmana. Zob. tamże. Zob. także: Sucharski, Literatura Holocaustu..., s. 98.

${ }^{51}$ Margolin, Podróż do krainy zeków..., s. 286.

52 Zob. Andrzej Drawicz, Spetniona misja sprzeciwu, [w:] Emigracja i tamizdat..., s. 118.

${ }_{53}$ Por. Krystyna Pietrzycka-Bohosiewicz, Historia zapisana $w$ człowieku... Wybrane problemy wolnej literatury rosyjskiej, Kraków 2008, s. 155. Zob. także: Katarzyna Duda, Andriej Amalrik - rosyjski dysydent, Kraków 2010, s. 144; Historia literatury rosyjskiej XX wieku, red. Andrzej Drawicz, Warszawa 1997, s. 564.

${ }^{54}$ Roman Katsman, Nieutowimaja riealnost'. Sto let russko-izrailskoj litieratury, „Artikl” 42 (2019), nr 10, https://sunround.com/article/?page_id=1386 [dostęp: 10 września 2019].

${ }_{55}$ Zob. Eugeniusz Czaplejewicz, Polska literatura łagrowa, Warszawa 1992, s. 32, 46.

${ }^{56}$ Zob. Stéphane Courtois, Nicolas Werth i in., Czarna księga komunizmu. Zbrodnie, terror, prześladowania, tłum. zbiorowe, przedmowa do wydania polskiego Krystyna Kersten, Warszawa 1999.

${ }^{57}$ Czaplejewicz, Polska literatura tagrowa ..., s. 46.

58 Por. tamże, s. 43-44. 
Margolin zachowuje w Podróży typową dla paktu autobiograficznego jednośćs ${ }^{59}$, gdzie autor występuje jednocześnie w roli świadka-uczestnika wydarzeń. I chociaż tekst nie jest w pełni wiarygodnym źródłem wiedzy historycznej, gdyż zawiera błędy i nieścisłości ${ }^{60}$, autentyczność relacji buduje autor pierwszoosobową narracją, w której obowiązuje chronologiczny, w wielu miejscach bardzo szczegółowy zapis wydarzeń ${ }^{61}$. Przy mocno rozbudowanych refleksjach antropologiczno-filozoficznych i komentarzach intelektualnie dojrzałych, osadzonych w szerokim kontekście historyczno-politycznym, ten linearny porządek pozwala zachować narracyjną spójność.

Pierwsze rozdziały wspomnień Margolina, pierwotnie najczęściej pomijane i usuwane przez cenzurę, to dokładna, rozpoczęta już we wrześniu 1939 r., relacja z terenów państwa polskiego zajętych przez siły zbrojne Związku Radzieckiego. Wiadomość o agresji Armii Czerwonej zastała narratora w Łodzi. Stamtąd, po nieudanych próbach wyjazdu do Palestyny, trafił na krótko do Lwowa, a następnie do rodzinnego Pińska. W pierwszym rozdziale autor drobiazgowo opisuje proces sowietyzacji Pińska i okolic, prace przy archiwizowaniu zbiorów bibliotecznych, pobyt w więzieniu i podróż w nieznane więziennym pociągiem. Kolejne trzy rozdziały, obejmujące pobyt w obozie Kwadrat 48, to opis obozowego życia, wyczekiwania na amnestię, zamieszkiwania w Kraju Ałtajskim i wyzwolenia w 1945 r.

Narrator, alter ego autora, jak typowy bohater wspomnień łagrowych odbył przymusową „podróż” do podziemnej Rosji. Droga, synonim tułaczego losu, od początku niesie negatywne konotacje, oznacza początek postępującej w tekście traumy ${ }^{62}$ :

Nie musiałem do Rosji jechać, ona sama do mnie przyjechała. Moja trasa była specyficzna, w Inturiście o takiej nie słyszano. Nie obserwowałem Rosji ani przez okno hotelu Metropol w Moskwie, ani też wagonu restauracyjnego. Oglądałem ją przez zakratowane okienko wagonu więziennego, zza obozowych drutów kolczastych ${ }^{63}$.

Podróż „wędrującą trumną" - wielu autorów relacji łagrowych stosuje podobne określenia ${ }^{64}$ - zyskuje miano demonicznej podróży do serca nocy,

${ }^{59}$ Philippe Lejeune, Pakt autobiograficzny, [w:] Wariacje na temat pewnego paktu. O autobiografii, red. Regina Lubas-Bartoszyńska, tłum. Wincenty Grajewski i in., Kraków 2001, s. 21.

${ }^{60}$ Zob. Czech, ...mówilibyśmy nie „archipelag GUŁag”, ale „kraina zeków”..., s. 13-14.

${ }^{61}$ Małgorzata Czermińska, O autobiografii i autobiograficzności, [w:] Autobiografia, red. Małgorzata Czermińska, Gdańsk 2009, s. 13.

${ }_{62}$ Zob. Sariusz-Skąpska, Polscy świadkowie GUŁagu..., s. 57-63.

${ }_{63}$ Margolin, Podróż do krainy zeków..., s. 3.

${ }^{64}$ Zob. Sucharski, Polskie poszukiwania „innej” Rosji... 
zjazdu do podziemi, do innego świata ${ }^{65}$. Pociąg z więźniami przemierza trasę z krainy słońca i uśmiechu do demonicznego królestwa, z którego nie ma odwrotu. Europa, Zachód, Palestyna są dla Margolina jasną stroną życia, tęsknotą i jednocześnie utopią, Rosja natomiast - mrocznym podziemiem, krajem niedoskonałym, marną karykaturą, tragiczną parodią zarówno europejskiego porządku, jak i Ziemi Obiecanej ${ }^{66}$.

Metaforyczny obraz państwa pokrytego „potworną wysypką” przypomina sołżenicynowską alegorię śmiertelnie chorej Rosji ${ }^{67} . \mathrm{Z}$ tą jednak różnicą, że u Margolina zamiast czysto funkcjonalnej roli przyrody i negatywnie nacechowanego sowieckiego krajobrazu, jak u Sołżenicyna czy Obertyńskiej ${ }^{68}$, obecne są fragmenty liryczne, w których natura nasuwa sielskie - włoskie, liguryjskie, europejskie - skojarzenia, sprzyja więźniom, wypełnia wewnętrzną pustkę, przynosi ukojenie:

Majestatycznie piękne są wiekowe lasy nad Onegą. Zimą to królestwo białego blasku, tęczowej gry barw, Niagara śniegów i takich bursztynowych, różowych i ciemnolazurowych zórz, jakby nad Karelią otworzyło się włoskie niebo. Głębia lasu jest niewzruszona, bezwietrzna, płomienie ognisk unoszą się prosto do nieba. Przyroda jest prześliczna i dziewiczo czysta, dopóki nie ma ludzi. Ludzie w tym lesie i to wszystko, co zbudowali, jest potwornie absurdalne, tak straszliwe, że wydaje się koszmarnym snem. Kto wymyślił tę mękę, komu potrzebni byli niewolnicy, konwojenci, karcery, błoto, głód i tortury? ${ }^{69}$.

Jedynie w zestawieniu z destrukcyjną siłą bestialskiego systemu i rozrastającą się skalą łagrowej zarazy przyroda ulega skażeniu, jest wyniszczona i przygnębiająca. Daleka Północ staje się wówczas wrogim żywiołem, bagnem, przestrzenią, w której ideologia bezhołowia igra z losem wrażliwego na piękno przyrody zachodniaka, humanisty, inteligenta ${ }^{70}$.

Chociaż narrator wiele razy zadaje typowe dla prozy obozowej pytania ${ }^{71}$ : „Za co?”, „Jakie prawo miały [władze sowieckie] wydrzeć z mojego życia najlepsze twórcze lata, pozbawić mnie twarzy, zdeptać, zamęczyć, uczynić niewolnikiem, doprowadzić do nędzy i rozpaczy moją rodzinę, położyć kres mojej działalności pisarskiej?"72, słuszna jest tylko jedna odpowiedź:

${ }^{65}$ Tamże.

${ }^{66}$ Katsman, Putieszestwije w stranu zeka..., s. 615.

${ }^{67}$ Drawicz, Chory kraj, chorzy ludzie..., 106.

${ }^{68}$ Zob. tamże, s. 111; Sucharski, Polskie poszukiwania „innej” Rosji...

69 Tamże.

${ }^{70}$ Zob. Margolin, Podróż do krainy zeków..., s. 157; Sariusz-Skąpska, Polscy świadkowie GUŁagu..., s. 236.

71 Tamże, s. 190.

72 Margolin, Podróż do krainy zeków..., s. 216. 
„Za winy niepopełnione" ᄁ3, zapożyczona od Ireny Wasilewskiej, studentki prawa zesłanej na Sybir w 1940 r. Cytat ten jest jednocześnie tytułem jej wspomnień wydanych w Rzymie pięć lat później.

Mamy w Podróży wyraźny podział wartości na „nasze”, europejskie - z europejskim latem, europejskimi swobodami, demokracją i z poszanowaniem godności osobistej, oraz „ich”, sowieckie - „barbarzyńskie, w pseudohumanitarnej otoczce”74: „My jesteśmy Europejczykami. Ten żydowski pociąg jest też cząstką Europy"75. Europocentryczna postawa Margolina pozwala mu krytykować bolszewicki świat dwuznaczności, dwulicowości, zakłamania i niedomówień ${ }^{76}$, ganić założenia koncepcji eurazjatyckiej. Eurazjaci zyskują miano ludzi niebezpiecznych, kulturowo ograniczonych, którzy nie posiadają „,europejskiego poczucia miary i taktu”"77. Ich tożsamość natomiast budowana jest na najgorszych podwalinach, jak ,europejski lęk, rozdwojenie, udręka poszukiwań, azjatycki despotyzm i ucisk jednostki”78.

Eurazjaci wyszli z Azji i nie doszli do Europy. Mogliby wziąć od Europejczyków i Azjatów to, co było w ich kulturach wielkiego i dobrego: ideę wolności obywatelskiej i godności ludzkiej z jednej strony, a z drugiej - ideę życia w jedności ze światem, życia pełnego mądrego spokoju i zadowolenia. Gdyby to wszystko połączyli, byliby najpotężniejszym narodem na świecie! ${ }^{79}$.

Już sam początek wspomnień Margolina, kiedy autor opisuje to, co się działo w Pińsku w roku 1940, przynosi obrazy przymuszania do miłości do nowej ojczyzny. Mieszkańcy miasta nie mają wyjścia, muszą się poddać powszechnej proletaryzacji, przyjmując wszystko, co przyniosła nowa władza: „Szarego człowieka zmuszono, by ukląkł przed państwem”»0. Państwo staje się u Margolina instytucją żądającą, nakazującą, bezwzględną:

Każdemu narodowi i każdemu społeczeństwu, poza najbardziej prymitywnymi, można narzucić ustrój radziecki, ale wyłącznie siłą. Normalny, naturalny bieg życia sprzeciwia się totalitarnemu, monopartyjnemu i maniakalnemu ustrojowi. [...] Można powiedzieć, że ilość zła i przemocy, ludzkich cierpień i nieszczęść, które

${ }^{73}$ Irena Wasilewska została deportowana do Rosji w 1941 r., pracowała w Biurze Opieki nad Polakami, pisała na temat losów dzieci deportowanych do Rosji Sowieckiej w latach 1939-1941. Zob. Irena Wasilewska, Za winy niepopetnione, Rzym 1945.

74 Margolin, Podróż do krainy zeków..., s. 143.

75 Tamże, s. 149.

${ }^{76}$ Por. Sucharski, Polskie poszukiwania ,innej” Rosji...

77 Margolin, Podróż do krainy zeków..., s. 148.

78 Tamże.

79 Tamże.

${ }^{80}$ Tamże, s. 68. 
[bolszewicy] wywołali w krótkim czasie, przewyższyła wszystko, co kraj ów wycierpiał przez szereg stuleci ${ }^{81}$.

Autor zestawia przy tym pojęcia: demokracja vs. despotia; wolność $v s$. terror; potrzeby, własna wola, uczucia $v s$. bezduszne doktrynerstwo, barbarzyństwo, nieludzkość. Komunistycznej traumy, jak twierdzi Margarete Buber-Neumann, która przeżyła zarówno sowiecki, jak i hitlerowski obóz koncentracyjny, nie można porównać z niczym na świecie ${ }^{82}$. Margolin myśli podobnie, ale zestawiając bezwzględne poczynania Sowietów z okrutnymi działaniami nazistów ${ }^{83}$, być może z tego powodu, że osobiście nie doświadczył prześladowań hitlerowców, mocniej piętnuje Sowietów:

Hitlerowskich obozów nie można porównać z waszymi. Ani co do rozmiarów, ani co to istoty. To drzazga, którą Europa wkrótce wyjmie ze swego ciała. Wasze obozy są trwałym systemem, logicznym zwieńczeniem reżimu. Europa może istnieć bez Hitlera i jego obozów, a władza radziecka bez obozów istnieć nie może ${ }^{84}$.

Zapisana w Podróży relacja o rzeczywistości podzielonej między niemieckie gestapo a sowieckie „genstapo” wypełniona jest opisami przeżyć wewnętrznych, wśród których nadzieja zmaga się z bezradnością:

Upał i spokój panowały nad rzeką, jej zielone brzegi porośnięte były trzciną, w zaroślach krzyczały ptaki. Dojeżdżałem do piaszczystej mielizny, rozbierałem się, kładłem na gorącym piasku i wpatrywałem w czyste niebo. Byłem sam i tylko kajak na mieliźnie łączył mnie z ohydnym, strasznym światem, gdzie miliony ludzi dusiły się między niemieckim gestapo a sowieckim „genstapo”. Z jednej strony Geheime Staatspolitzei, tajna policja, z drugiej - ,genialna stalinowska polityka”, a w środku - leżący na piasku człowiek, nagi i bezbronny. Bez praw i bez wyjścia, bez ojczyzny i łączności ze światem zewnętrznym, okłamany, zaszczuty, zagnany w ślepą uliczkę i skazany na śmierćs ${ }^{85}$.

Wojnę niemiecko-rosyjską nazywa Margolin wojną goryli z ludożercami $^{86}$. Polskę porównuje do ofiary rozszarpywanej przez dwóch bezwzględnych drapieżników. Pisze o kłamstwie i okrucieństwie, jakie musieli znosić mieszkańcy miast przyłączonych zarówno do hitlerowskich Niemiec, jak i do sowieckiej Rosji: „Ktoś zamknął nam usta i mówił w naszym imieniu.

81 Tamże, s. 76.

82 Por. Andrzej Józef Kamiński, Koszmar niewolnictwa. Obozy koncentracyjne od 1896 do dziś. Analiza, Warszawa 1990, s. 19.

${ }^{83}$ Por. tamże. Zob. także: Sucharski, Polskie poszukiwania „innej” Rosji...

${ }^{84}$ Margolin, Podróż do krainy zeków..., s. 167.

85 Tamże, s. 46.

86 Tamże, s. 188. 
Ktoś wszedł do naszego domu, wkroczył w nasze życie i zaczął się w nim gospodarzyć bez naszej zgody" ${ }^{87}$ - czytamy w Podróży. Oczywiście nie ma wątpliwości, że Margolin dostrzegał różnicę między sowieckimi i nazistowskimi obozami koncentracyjnymi. Zestawiając hitlerowskie obozy „ostatecznego rozwiązania” z sowieckim ,archipelagiem śmierci na bezprecedensową skalę" ${ }^{88}$, pisarz zdecydowanie potępia oba systemy.

Właściwie należałoby ubolewać, że świadectwo Margolina nie zostało dotąd całościowo odczytane i zinterpretowane (jedynym tekstem naukowym o Podróży, do którego udało mi się dotrzeć, jest przywoływany artykuł Romana Katsmana). Jest ono bowiem jedną z pierwszych relacji łagrowych, wyjątkowo rzetelnym, dokładnym i bogatym zapisem obozowych doświadczeń. Na szczęście nigdy nie jest za późno i każdy czas jest właściwy, aby przywracać „niechcianą pamięć”" , czego dowodem jest rozkwit literatury memorialnej w ostatnich latach ${ }^{90}$. Margolin, odbywając niewolniczą podróż w głąb sowieckiej Rosji, gruntownie rozpoznaje, penetruje i przeżywa ową przestrzeń, a jednocześnie bada mechanizmy ludzkich postępowań w skrajnie trudnych warunkach ${ }^{91}$. Tym samym do końca odpowiedzialnie walczy o ludzką godność, nie tracąc wiary w człowieka nawet w „obozowym piekle". Autor ma przy tym niepospolitą umiejętność widzenia i opowiadania tego świata i ludzkich doświadczeń. Dobrze zatem się stało, że jego głos w końcu ma szansę wybrzmieć.

\section{Bibliografia}

\section{1. Źródła opublikowane}

Margolin Julij Borisowicz, Putieszestwije w stranu ze-ka. Priedistowije, Nju Jork 1952, http://lib.ru/MEMUARY/MARGOLIN/Puteshestvie_v_stranu_ze-ka.txt [dostęp: 17 stycznia 2019].

Margolin Julij, Putieszestwije w stranu Zeka i doroga na Zapad, Jerozolima 2017.

87 Tamże, s. 72.

${ }^{88}$ Por. Norman Davies, Europa - między Wschodem a Zachodem, tłum. Bartłomiej Pietrzyk, Kraków 2007.

${ }^{89}$ Ryszard Kapuściński, O pamięci i jej zagrożeniach z Ryszardem Kapuścińskim rozmawiaja Zbigniew Benedyktowicz i Dariusz Czaja, ,Konteksty” 57 (2003), nr 3-4, s. 12-24.

${ }_{90}$ Zob. Magdalena Saryusz-Wolska, Spotkania czasu z miejscem. Studia o pamięci i miastach, Warszawa 2011, s. 67; Elżbieta Rybicka, Miejsce, pamięć, literatura (w perspektywie geopolityki), „Teksty Drugie” (2008), nr 1-2, s. 19.

${ }_{91}$ Zob. Sariusz-Skąpska, Polscy świadkowie GUŁagu ..., s. 332; Małgorzata Całka, Z badań nad literatura tagrowa w Polsce, „Acta Universitatis Lodziensis. Folia Librorum” 10 (2001), s. 143; Izabela Kowalska-Paszt, Proza niefikcjonalna Abrama Terca. „Gtos z chóru” jako wspótczesna „silva rerum”, „Slavia Orientalis” 49 (2000), nr 4, s. 526. 
Margolin Julij, Wiesti iz Rossii. Dieło Biergiera (Otkrytoje pis'mo), Czernowik, pieriepieczatannyj na maszynkie po-russki, „Socyalisticzeskij Wiestnik” (1946), nr 12, http://rjews.net/raisa-epshtein/articles/margolin/6.htm [dostęp: 7 września 2018].

Margolin Julius, Podróż do krainy zeków, tłum. Jerzy Czech, Wołowiec 2013.

\section{Opracowania}

Autobiografia, red. Małgorzata Czermińska, Gdańsk 2009.

Bobrownicka Maria, Suchanek Lucjan, Ziejka Franciszek, Wspótcześni Słowianie wobec własnych tradycji i mitów. Sympozjum w Castel Gandolfo 19-20 sierpnia 1996, Kraków 1997.

Całka Małgorzata, Z badań nad literatura łagrowa w Polsce, „Acta Universitatis Lodziensis. Folia Librorum" 10 (2001).

Chazan Władimir, Czełowiek, kotoryj byt „sam po siebie”. O Julii Margolinie, „Lechaim” 6 (ijun' 2010 / siwan 5770), https://lechaim.ru/ARHIV/218/hazan. htm [dostęp: 20 września 2018].

Courtois Stéphane, Werth Nicolas i in., Czarna księga komunizmu. Zbrodnie, terror, prześladowania, tłum. zbiorowe, przedmowa do wydania polskiego Krystyna Kersten, Warszawa 1999.

Czaplejewicz Eugeniusz, Polska literatura łagrowa, Warszawa 1992.

Czech Jerzy, ...mówilibyśmy nie „archipelag GUŁag”, ale „kraina zeków”, [w:] Julius Margolin, Podróż do krainy zeków, Wołowiec 2013.

Cziżyk S. N., Sud'ba odnoj prokłamacyi: izrailskij kommunizm protiw Julija Margolina. Sobranije statiej $i$ wystuplenij, obraszczenij i pisiem Julija Margolina 1946-1957 gg., Jerozolima 2002.

Dać świadectwo prawdzie. Portrety współczesnych pisarzy rosyjskich, red. Lucjan Suchanek, Kraków 1996.

Davies Norman, Europa - między Wschodem a Zachodem, tłum. Bartłomiej Pietrzyk, Kraków 2007.

Dobruskina Irina, Iz awtobiograficzeskich matieriatow i publicystiki, „Lethaea Rossica" 9 (2014).

Duda Katarzyna, Andriej Amalrik - rosyjski dysydent, Kraków 2010.

Emigracja i tamizdat. Szkice o współczesnej prozie rosyjskiej, red. Lucjan Suchanek, Kraków 1993.

Fromier Władimir, Wmiesto poslestowija. Niesostojawszajasia wstriecza, [w:] Julij Margolin, Putieszestwije w stranu Zeka i doroga na Zapad, II, Jerozolima 2017.

Gul Roman, Ja unios Rossiju. Apołogija emigracyi, t. 1: Rossija w Giermanii, Moskwa 2001.

Historia literatury rosyjskiej XX wieku, red. Andrzej Drawicz, Warszawa 1997.

Jackowska Anna Maria, Julius Margolin - świadek zagłady żydowskiej w obozach sowieckich. Przyczynek do dziejów zimnej wojny, „Dzieje Najnowsze” 43 (2011), nr 3.

Jakobson Anatolij, Fragmienty iz Margolina (Popytka riekwijema), http://www. antho.net/library/ yacobson/texts/margolin.html [dostęp: 16 stycznia 2019]. 
Kamiński Andrzej Józef, Koszmar niewolnictwa. Obozy koncentracyjne od 1896 do dziś. Analiza, Warszawa 1990.

Kapuściński Ryszard, O pamięci i jej zagrożeniach z Ryszardem Kapuścińskim rozmawiają Zbigniew Benedyktowicz i Dariusz Czaja, „Konteksty” 57 (2003), nr 3-4.

Katsman Roman, Nieułowimaja riealnost'. Sto let russko-izrailskoj litieratury, „Artikl” 42 (2019), nr 10.

Katsman Roman, Putieszestwije w stranu zeka. Poeticzeskaja zagadka Julija Margolina, „Slavia Orientalis” 67 (2018), nr 4.

Kowalska-Paszt Izabela, Proza niefikcjonalna Abrama Terca. „Głos z chóru” jako wspótczesna „silva rerum”, „Slavia Orientalis” 49 (2000), nr 4.

Kowalska-Paszt Izabela, Proza niefikcjonalna trzeciej fali emigracji rosyjskiej. Model typologiczny, Szczecin 2001.

Lejeune Philippe, Wariacje na temat pewnego paktu. O autobiografii, red. Regina Lubas-Bartoszyńska, tłum. Wincenty Grajewski i in., Kraków 2001.

Pierzchała Kazimierz, Rosyjski system penitencjarny w ujęciu wybranych polskich i rosyjskich opracowań, „Nowa Polityka Wschodnia” (2017), nr 4.

Pietrzycka-Bohosiewicz Krystyna, Historia zapisana w człowieku... Wybrane problemy wolnej literatury rosyjskiej, Kraków 2008.

Rybicka Elżbieta, Miejsce, pamięć, literatura (w perspektywie geopolityki), „Teksty Drugie" (2008), nr 1-2.

Sariusz-Skąpska Izabella, Polscy świadkowie GUŁagu. Literatura łagrowa 1939-1945, Kraków 1995.

Saryusz-Wolska Magdalena, Spotkania czasu z miejscem. Studia o pamięci i miastach, Warszawa 2011.

Sucharski Tadeusz, Literackie świadectwa polskich Żydów ze Związku Sowieckiego (z czasów II wojny światowej), [w:] Żydzi wschodniej Polski, Seria 2: Wblasku i cieniu historii, red. Jarosław Ławski, Barbara Olech, Białystok 2014.

Sucharski Tadeusz, Literatura Holocaustu i literatura Gułagu? Literatura doświadczenia totalitarnego!, „Słupskie Prace Filologiczne. Filologia Polska” 5 (2007).

Sucharski Tadeusz, Polskie poszukiwania „innej” Rosji. O nurcie rosyjskim w literaturze Drugiej Emigracji, Gdańsk 2008.

Sukiennicki Wiktor, Z ziemi nieludzkiej - relacje obcych $i$ swoich, „Kultura” (1950), nr 11 (37).

Szauli Misza, K priezientacyi dwuchtomnika Julija Margolina, http://www.newswe. com/index.php?go=Pages\&in=view\&id=9186 [dostęp: 11 września 2018].

Wasilewska Irena, Za winy niepopetnione, Rzym 1945.

Winokurowa Irina, Nie mogu siebie priedstawit', cztoby kniga nie wyszła po-russki... Kursiw moj: $k$ istorii publikacyi i riecepcyi, „Znamia” (2017), nr 12, http://magazines.russ.ru/znamia/2017/12/ne-mogu-sebe-predstavit-chtoby-kniga-ne-vyshla-po-russki-pr.html [dostęp: 26 stycznia 2019]. 